\title{
EXPERIMENTAL STUDY ON THE ORIGIN OF CREMATED BONE APATITE CARBON
}

\author{
C M Hüls ${ }^{1}$ H Erlenkeuser $・$ M-J Nadeau $・$ P M Grootes $•$ N Andersen \\ Leibniz Laboratory for Radiometric Dating and Isotope Research, Christian-Albrechts-University, Kiel, Germany.
}

\begin{abstract}
Bones that have undergone burning at high temperatures (i.e. cremation) no longer contain organic carbon. Lanting et al. (2001) proposed that some of the original structural carbonate, formed during bioapatite formation, survives. This view is based on paired radiocarbon dating of cremated bone apatite and contemporary charcoal. However, stable carbon isotope composition of carbonate in cremated bones is consistently light compared to the untreated material and is closer to the $\delta^{13} \mathrm{C}$ values seen in $\mathrm{C}_{3}$ plant material. This raises the question of the origin of carbonate carbon in cremated bone apatite. That is, does the isotope signal reflect an exchange of carbon with the local cremation atmosphere and thus with carbon from the burning fuel, or is it caused by isotopic fractionation during cremation?

To study the changes in carbon isotopes $\left({ }^{14} \mathrm{C},{ }^{13} \mathrm{C}\right)$ of bone apatite during burning up to $800{ }^{\circ} \mathrm{C}$, a modern bovine bone was exposed to a continuous flow of an artificial atmosphere (basically a high-purity $\mathrm{O}_{2} / \mathrm{N}_{2}$ gas mix) under defined conditions (temperature, gas composition). To simulate the influence of the fuel carbon available under real cremation conditions, fossil $\mathrm{CO}_{2}$ was added at different concentrations. To yield cremated bone apatite properties similar to archaeological cremated bones, in terms of crystallographic criteria, water vapor had to be added to the atmosphere in the oven. Infrared vibrational spectra reveal large increases in crystal size and loss of carbonate upon cremation. The isotope results indicate an effective carbon exchange between bone apatite carbonate and $\mathrm{CO}_{2}$ in the combustion gases depending on temperature and $\mathrm{CO}_{2}$ concentration. ${ }^{14} \mathrm{C}$ dates on archaeological cremated bone apatite may thus suffer from an old-wood effect. Paired ${ }^{13} \mathrm{C}$ and ${ }^{14} \mathrm{C}$ values indicate that in addition to this exchange, isotope fractionation between $\mathrm{CO}_{2}$ and carbonate, and admixture of carbon from other sources such as possibly collagen or atmospheric $\mathrm{CO}_{2}$, may play a role in determining the final composition of the apatite carbonate.
\end{abstract}

\section{INTRODUCTION}

Bone is a composite of organic (predominantly collagen) and inorganic (mineral) material. The mineral phase is bioapatite, a calcium phosphate close to natural abiotic apatites in a non-stoichiometric composition. An overall range of bioapatite chemistry is given by Skinner (2005) as $(\mathrm{Ca}, \mathrm{Na}, \mathrm{Mg}$, $\mathrm{K}, \mathrm{Sr}, \mathrm{Pb}, \ldots)_{10}\left(\mathrm{PO}_{4}, \mathrm{CO}_{3}, \mathrm{SO}_{4}, \ldots\right)_{6}\left(\mathrm{OH}, \mathrm{F}, \mathrm{Cl}, \mathrm{CO}_{3}\right)_{2}$. Cazalbou et al. (2004) use $\mathrm{Ca}_{8.3 \mathrm{a}} .7$ $\left(\mathrm{PO}_{4}\right)_{4.3}\left(\mathrm{HPO}_{4} \text { and } \mathrm{CO}_{3}\right)_{1.7}\left(\mathrm{OH} \text { or } 0.5 \mathrm{CO}_{3}\right)_{0.3 \mathrm{al} .7}$ to emphasize the role of structural carbonate for bioapatite properties, e.g. crystal size, crystal strain, solubility, etc. (where $\mathbf{\square}$ indicates a vacancy, i.e. unfilled site, in the structure). Structural carbonate $\left(\mathrm{CO}_{3}{ }^{2-}\right)$ can be substituted for the phosphate $\left(\mathrm{PO}_{4}{ }^{3-}\right)$ or the hydroxyl $\left(\mathrm{OH}^{-}\right)$(B-type carbonate and A-type carbonate, respectively), where differences in the charge state of the substituent are balanced by empty positions in the crystal lattice. Studies on bone apatite, as well as synthetic apatites, have shown that precipitation at body temperature favors the B-type carbonate substitution (Elliott 2002).

Up to $6 \mathrm{wt} \% \mathrm{CO}_{3}{ }^{2-}(\sim 1.2 \mathrm{wt} \% \mathrm{C})$, which originates from blood bicarbonate generated by energy metabolism in the cells, can be substituted into bone apatite as so-called structural carbonate. Although radiocarbon dating of bone apatite is possible in principle, it has been avoided in the past due to the large potential for ion exchange during bone deposition and postburial degradation (Berger et al. 1964; Tamers and Pearson 1965). Recently, a number of studies have shown that ${ }^{14} \mathrm{C}$ dating of cremated bones (i.e. bones burnt at temperatures $>600{ }^{\circ} \mathrm{C}$ ) gives apparent apatite ages that are in close agreement with those of contemporaneous organic material (Lanting and Brindley 2000; Lanting et al. 2001; De Mulder and Van Strydonck 2004; Van Strydonck et al. 2005; De Mulder et al. 2007; Olsen et al. 2008).

${ }^{1}$ Corresponding author. Email: mhuels@leibniz.uni-kiel.de.

(C) 2010 by the Arizona Board of Regents on behalf of the University of Arizona Proceedings of the 20th International Radiocarbon Conference, edited by A J T Jull RADIOCARBON, Vol 52, Nr 2-3, 2010, p 587-599 
Cremation of bones results in specific changes in apatite properties such as: total loss of organics; substantial loss of carbonate; and a significant increase in crystallinity and crystal size as well as enhanced friability (Shipman et al. 1984; Stiner et al. 1995). The increased crystal size of burnt apatite, from a few tens of $\mathrm{nm}$ in fresh bones to $>100 \mathrm{~nm}$ in cremated bones (Enzo et al. 2007; Piga et al. 2008), is thought to preserve the remaining structural carbonate ( $\sim 0.1 \mathrm{wt} \%)$ against ion exchange while the bone is buried in the soil (Lanting et al. 2001).

The generally good agreement between burnt apatite and contemporaneous organic material seems to support this assumption. However, burnt apatite $\delta^{13} \mathrm{C}$ values are in general depleted compared to unburnt bone apatite $(<-21 \%$ and $>-17 \%$, respectively; Bocherens 2002; Lee-Thorp and Sponheimer 2003). For instance, Olsen et al. (2008) reported $\delta^{13} \mathrm{C}$ values from a single bone with visual and crystallographic features varying from nearly fresh to fully cremated with a large depletion in $\delta^{13} \mathrm{C}$ in the cremated part. Surovell (2000), in burning apatite from a 10-kyr-old mammoth at $800{ }^{\circ} \mathrm{C}$ to remove possible secondary calcite, found it to contain bomb ${ }^{14} \mathrm{C}$, thus clearly indicating carbon exchange during combustion. This raises the question what the isotopic composition of the carbonate in cremated bone apatite is indicative of: the original apatite carbonate, carbon exchange, and/or isotopic fractionation during cremation?

To understand the origin of carbon in cremated bone apatite, we have conducted burning experiments with a modern fresh bovine bone under controlled conditions of variable temperature and composition of the burning atmosphere.

\section{MATERIALS AND METHODS}

Pieces $(0.5-1 \mathrm{~cm}$ thick, $1-2 \mathrm{~cm}$ wide, and 1 to $\sim 5 \mathrm{~cm}$ long) of a fresh bovine bone (cortical bone from femur) were scraped and defleshed using a scalpel, then burnt at temperatures from 500 to $800^{\circ} \mathrm{C}$ under different artificial atmospheres in a flow-through burning reactor (quartz tube with 2 burning chambers; see Figure 1, Tables 1 and 2). To investigate the influence of burning fuel carbon, old (i.e. almost dead) $\mathrm{CO}_{2}$ (Table 2) was admixed into a pure $\mathrm{O}_{2} / \mathrm{N}_{2}$ mixture (Table 1). In the first set of experiments, the burning atmosphere $\left(\mathrm{O}_{2} / \mathrm{N}_{2}\right.$ with and without $\left.\mathrm{CO}_{2}\right)$ was directed through a bath of ultrapure water at room temperature before entering the oven ("wet" burning). This procedure simulates a burning atmosphere with some water vapor as for natural burning processes. In a second set of experiments, no moisture was added ("dry" burning). The experimental system is leakproof. It is terminated by a demineralized water buffer to prevent backward diffusion of external gases. $\mathrm{CO}_{2}$ blanks (no bone sample) were tested trapping the gas after the oven. The blank was $<0.007 \mathrm{mg}$ $\mathrm{C}$, applying a $\mathrm{CO}_{2}$-free $\mathrm{O}_{2} / \mathrm{N}_{2}$-burning gas flowing at $0.1 \mathrm{~L} /$ min under common combustion conditions $\left(500 / 800^{\circ} \mathrm{C}\right)$ for $0.5 \mathrm{hr}$. This blank was considered insignificant.

After burning, the sample material was allowed to cool down to $<100{ }^{\circ} \mathrm{C}$ under continuing gas flow before removal from the oven. The sample material was stored in glass containers under Ar gas to prevent contamination with the atmosphere in the long term. Approximately 5-10 $\mathrm{mg}$ of sample material was taken from 2 to 3 bone pieces for analysis with Fourier-transform infrared spectroscopy (FTIR) and $\sim 300 \mathrm{mg}$ for X-ray diffractometry (XRD). The pieces were sampled with a dentist tool on the outside and inside and then powdered in a ball mill. FTIR was performed on a Nicolet $308^{\mathrm{TM}}$ in ATR mode (attenuated total reflection, diamond crystal, 400 to $4000 \mathrm{~cm}^{-1}$ wavelength). Changes in crystallinity were estimated using the splitting factor (SF) of the $v_{4}$ vibration mode of $\mathrm{PO}_{4}{ }^{3-}$ between 495 and $750 \mathrm{~cm}^{-1}$ (Weiner and Bar-Yosef 1990). Since no difference is observed between SF values from the outside and inside samples, all measurements from the different experiments were pooled. Single XRD analyses were performed on a Bruker D8-advance with a copper cathode $(\mathrm{CuK} \alpha)$ with $\sim 300 \mathrm{mg}$ powdered sample material. The crystallinity index (CI) was calcu- 
Artificial atmosphere:

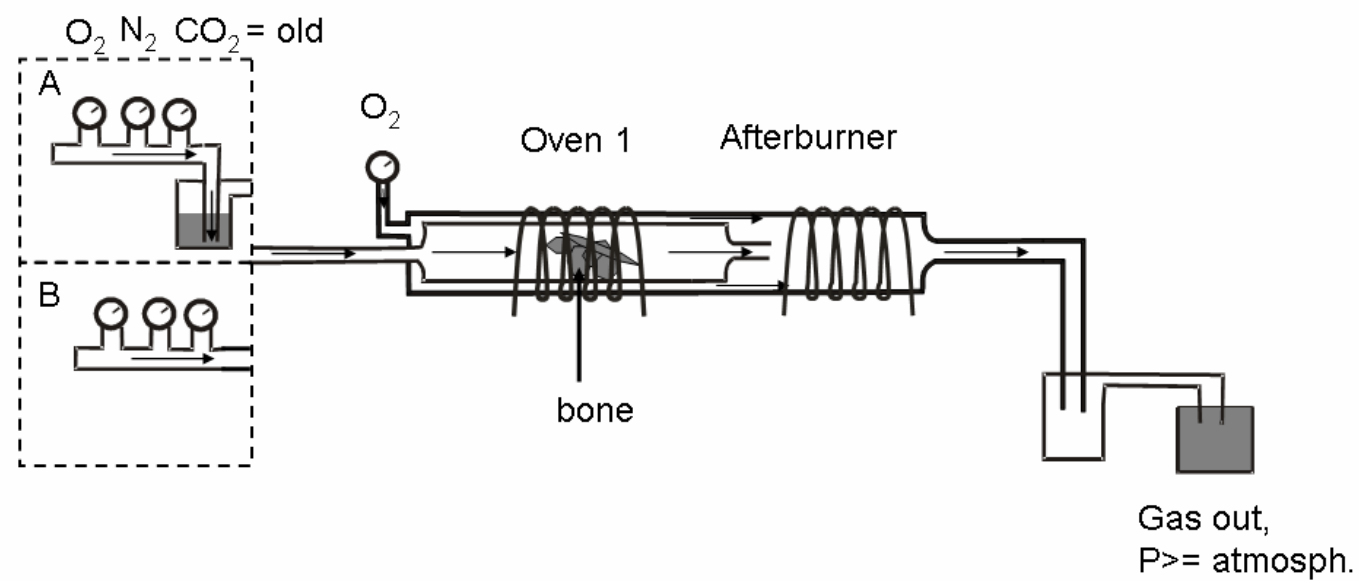

Figure 1 Experimental layout of cremation tests: A) burning atmosphere $\left(\mathrm{O}_{2}-\mathrm{N}_{2}\right.$ mixture, with and without old $\mathrm{CO}_{2}$, is directed through ultrapure water into the burning chamber ("wet" combustion); B) burning atmosphere is fed directly into the burning chamber ("dry" combustion). To prevent the outer atmosphere from diffusing in the system, burning gas is discharged through ultrapure water. During the experiment, the gas flow in the system raises the pressure within the system above atmospheric pressure.

Table 1 Conditions for the cremation experiments.

\begin{tabular}{|c|c|c|c|c|c|c|c|}
\hline $\begin{array}{l}\text { Experiment } \\
\mathrm{nr}\end{array}$ & $\begin{array}{l}\text { Temperature } \\
\left({ }^{\circ} \mathrm{C}\right)\end{array}$ & $\begin{array}{l}\text { Duration } \\
\text { (hr) }\end{array}$ & $\begin{array}{l}\text { Weight } \\
\text { (g) }\end{array}$ & $\begin{array}{l}\sum \text { gas flow } \\
\text { (mL/min) }\end{array}$ & $\begin{array}{l}\mathrm{CO}_{2} \\
(\mathrm{~mL} / \mathrm{min})\end{array}$ & $\begin{array}{l}\mathrm{N}_{2} \\
(\mathrm{~mL} / \mathrm{min})\end{array}$ & $\begin{array}{l}\mathrm{O}_{2} \\
(\mathrm{~mL} / \mathrm{min})\end{array}$ \\
\hline \multicolumn{8}{|c|}{ Wet combustion } \\
\hline 4 & 800 & 4.0 & 6.46 & 90 & 0 & 70 & 20 \\
\hline 11 & 800 & 4.4 & 15.00 & 70 & 0 & 55 & 15 \\
\hline 3 & 800 & 3.8 & 14.99 & 101 & 2 & 79 & 20 \\
\hline 5 & 800 & 4.3 & 8.43 & 100 & 10 & 70 & 20 \\
\hline 6 & 800 & 4.0 & 6.99 & 70 & 10 & 50 & 10 \\
\hline 7 & 700 & 4.5 & 8.02 & 70 & 10 & 50 & 10 \\
\hline 10 & 650 & 4.0 & 8.46 & 70 & 10 & 50 & 10 \\
\hline 8 & 600 & 4.5 & 15.00 & 70 & 10 & 50 & 10 \\
\hline 9 & 500 & 4.3 & 14.99 & 70 & 10 & 50 & 10 \\
\hline \multicolumn{8}{|c|}{ Dry combustion } \\
\hline 1 & 800 & 4.5 & 14.96 & 108 & 18 & 80 & 20 \\
\hline 2 & 800 & 7.5 & 14.96 & 108 & 18 & 80 & 20 \\
\hline
\end{tabular}

Table $2{ }^{14} \mathrm{C}$ and ${ }^{13} \mathrm{C}$ concentrations for bone and $\mathrm{CO}_{2}$.

\begin{tabular}{|c|c|c|c|c|c|c|}
\hline $\begin{array}{l}\text { Sample } \\
\text { name }\end{array}$ & $\begin{array}{l}\text { Sample } \\
\text { fraction }\end{array}$ & D & $\begin{array}{l}\text { Correc } \\
\text { pMC }\end{array}$ & $\begin{array}{l}\text { Uncorr } \\
\text { pMC }\end{array}$ & $\begin{array}{l}\delta^{13} \mathrm{C} \\
\left(\%{ }^{\circ} \mathrm{VDB}\right)^{\mathrm{a}}\end{array}$ & $\begin{array}{l}\delta^{13} \mathrm{C} \\
(\% \text { VPDB })^{\mathrm{b}}\end{array}$ \\
\hline 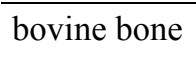 & & $\mathrm{K}$ & 9 & 9 & -13 & \\
\hline & & & & & & \\
\hline $1 d \mathrm{CO}_{2}$ & $\mathrm{CO}_{2}$ & KIA 39049 & $0.23 \pm 0.03$ & $0.23 \pm 0.03$ & $-31.95 \pm 0.2$ & $-32.60 \pm 0.1$ \\
\hline
\end{tabular}

aMeasured with the AMS system.

${ }^{\mathrm{b}}$ Measured with conventional mass spectrometry. 
lated following Person et al. (1995) using the separation of the peaks corresponding to reflections [211], [112], [300], and [202] (see Figure 2).
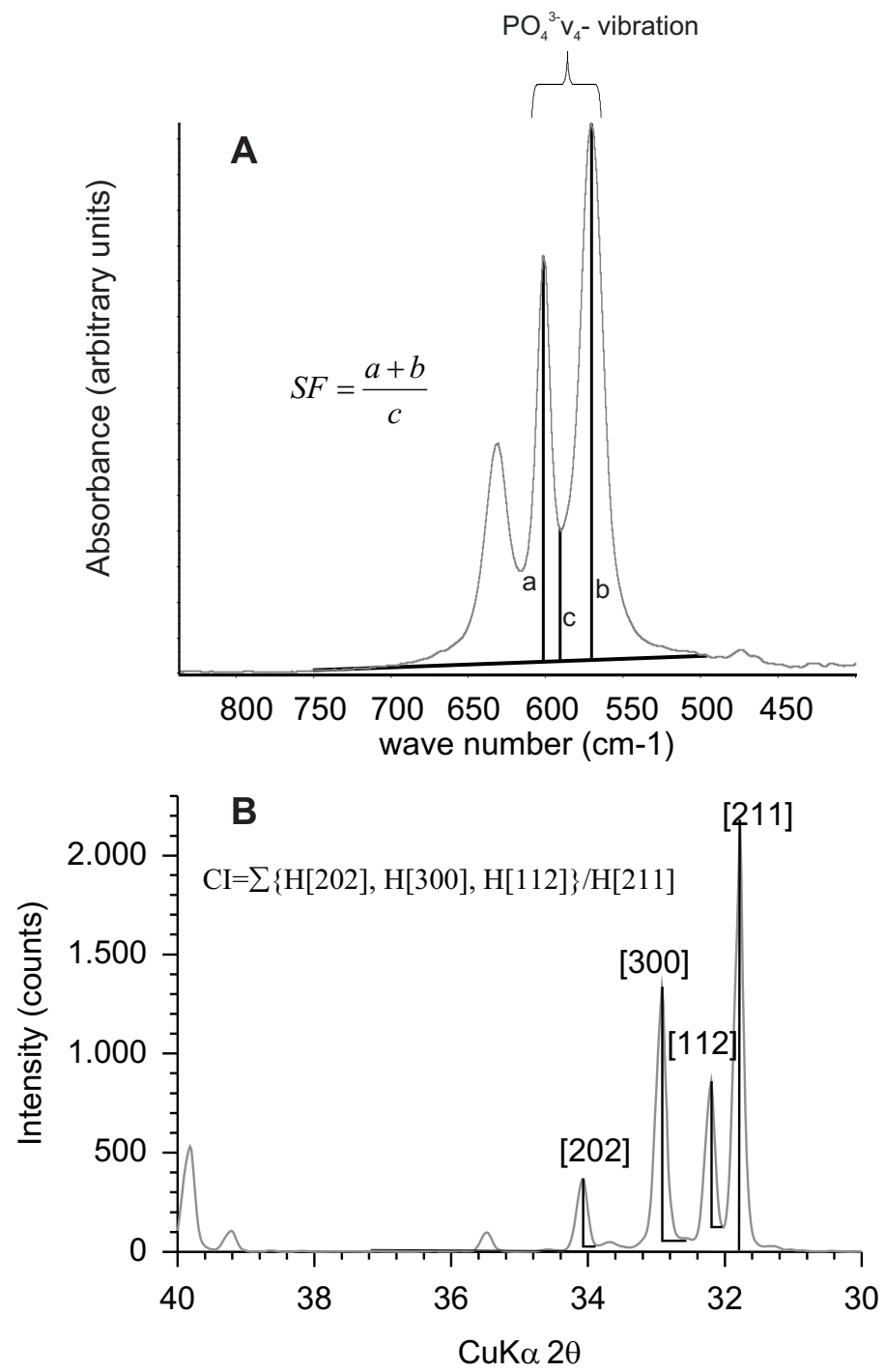

Figure 2 A) Part of the FTIR spectra of sample 4 illustrating the calculation of the FTIR splitting factor. A baseline is drawn between 750 and $495 \mathrm{~cm}^{-1}$. The heights of the peaks at $\sim 602$ and $565 \mathrm{~cm}^{-1}$ are summed and divided by the height of the valley between them (Weiner and Bar-Yosef 1990). B) Definition of the crystallinity index by XRD using the refraction peaks [202], [300], [112], and [211] (Person et al. 1995).

Sample $\mathrm{CO}_{2}$ for isotopic measurements (accelerator mass spectrometry [AMS] and gas isotope ratio mass spectrometry [MS]) was liberated from $\sim 1 \mathrm{~g}$ of sample material with $4 \mathrm{~mL}$ of $60 \%$ phosphoric acid at $90{ }^{\circ} \mathrm{C}$ in a sealed ampoule reaction system (Nadeau et al. 2001). Before graphitization for subsequent AMS measurements, possible sulfur dioxide was removed by reacting the sample gas 
with $\mathrm{CuO}$ and silver wool in a quartz tube at $900{ }^{\circ} \mathrm{C}$ for $4 \mathrm{hr}$. The sample $\mathrm{CO}_{2}$ was graphitized and measured at the Leibniz-Labor AMS system using standard procedures (Nadeau et al. 1997, 1998). Isotope mass spectrometry was done directly on extracted $\mathrm{CO}_{2}$ on a Finnigan Delta $\mathrm{E}^{\mathrm{TM}}$ instrument. Stable carbon isotope ratios are given in the $\delta^{13} \mathrm{C}$ notation versus VPDB standard; errors are 1 standard deviation (Tables 2 and 3).

The carbon in the burnt bone apatite may be from original bone apatite carbonate, bone collagen, and/or burning fuel carbon (old $\mathrm{CO}_{2}$ in the experiment):

$$
C_{\mathrm{HAP}-\text { burnt }}=C_{\mathrm{HAP}-\text { org }}+C_{\mathrm{col}}+C_{\mathrm{oldCO} 2}
$$

where $\mathrm{C}_{\text {HAP-burnt }}$ is carbon in burnt bone apatite, $\mathrm{C}_{\mathrm{HAP}-\text { org }}$ is carbon from original bone apatite, $\mathrm{C}_{\text {col }}$ is collagen carbon, and $\mathrm{C}_{\text {oldCO2 }}$ is carbon from old $\mathrm{CO}_{2}$, admixed during combustion.

Original apatite carbon and collagen carbon have essentially the same ${ }^{14} \mathrm{C}$ signature, so the contribution of carbon from old $\mathrm{CO}_{2} M$ can be estimated directly from the measured ${ }^{14} \mathrm{C}$ concentration of burnt bone apatite by:

$$
M=\frac{{ }^{14} C_{\text {HAP-org }}-{ }^{14} C_{\text {HAP-burnt }}}{} * 100(\%)
$$

Since collagen carbon and the old $\mathrm{CO}_{2}$ have different $\delta^{13} \mathrm{C}$ signatures compared to bone apatite carbon, we use uncorrected ${ }^{14} \mathrm{C}$ concentrations in percent modern carbon $\left(\mathrm{pMC}_{\text {uncorr }}\right)$ to estimate an assumed carbon exchange.

\section{RESULTS}

\section{Chemical and Mineralogical Changes}

Chemical and mineralogical changes of the bone occurring during the burning $\left(<600{ }^{\circ} \mathrm{C}\right)$ and cremation $\left(>600^{\circ} \mathrm{C}\right)$ experiments were documented by FTIR and XRD analysis (Figures 3, 4). In general, the resulting material changes are similar to those found in real archaeological cremated bone (VIRI 4), e.g. loss of organics and carbonate with a main hydroxylapatite phase (HAp) plus a fraction of carbonated hydroxylapatite (cHAp) in conjunction with changes in crystallinity reflected by a change in SF from $\sim 3$ to $>5$ and in $\mathrm{CI}$ from $<0.4$ to $>0.8$ (from fresh to cremated).

However, a significant difference with respect to carbonate substitution is observed between materials cremated in the wet or dry conditions. Material cremated $\left(>600{ }^{\circ} \mathrm{C}\right)$ under wet conditions shows a large depletion in carbonate content in general with only a fraction of carbonate substituted for $\mathrm{PO}_{4}{ }^{3-}$ (B-type, $\mathrm{C}$ content $\sim 0.1-0.4 \mathrm{wt} \%$; Table 3), which is similar to archaeological cremated bones. On the other hand, material cremated under dry conditions showed a higher carbon content ( $\sim 0.7 \mathrm{wt} \%$, experiments 1 and 2) with carbonate substitution for $\mathrm{PO}_{4}{ }^{3-}$ as well as for $\mathrm{OH}^{-}$(B-type and A-type, respectively). Previous work also suggested a higher A-type carbonate substitution when water is excluded from the mineralization environment (LeGeros et al. 1969). Interestingly, SF for dry-combusted material (SF $~ 3.5$ ) would indicate a smaller crystallite size if the relationship to crystallite size of Trueman et al. (2004) is applied, whereas CI (CI 1.3) clearly indicates an increase, which is also confirmed by transmission electron microscopy (TEM) of wet and dry cremated material (unpublished data). 


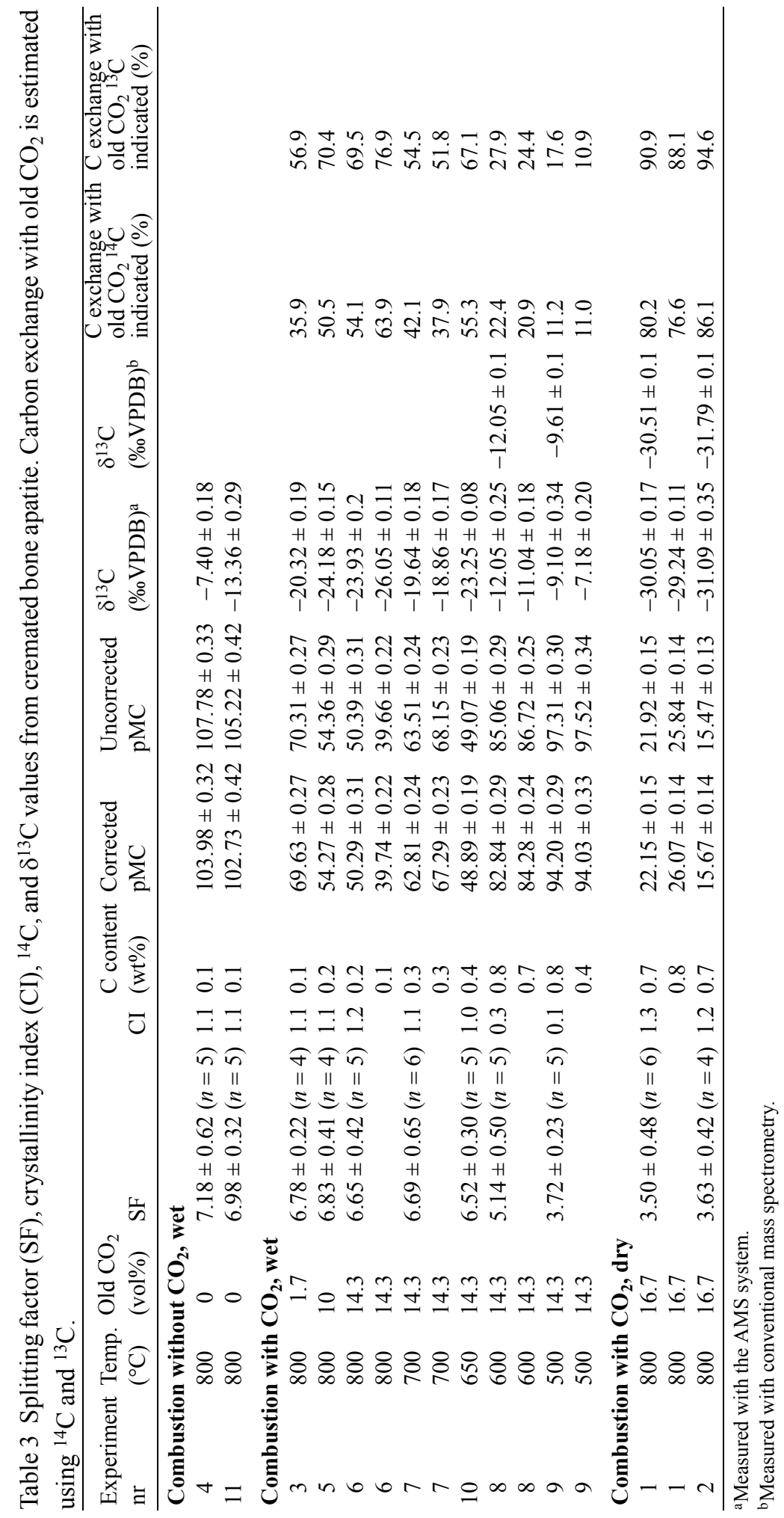




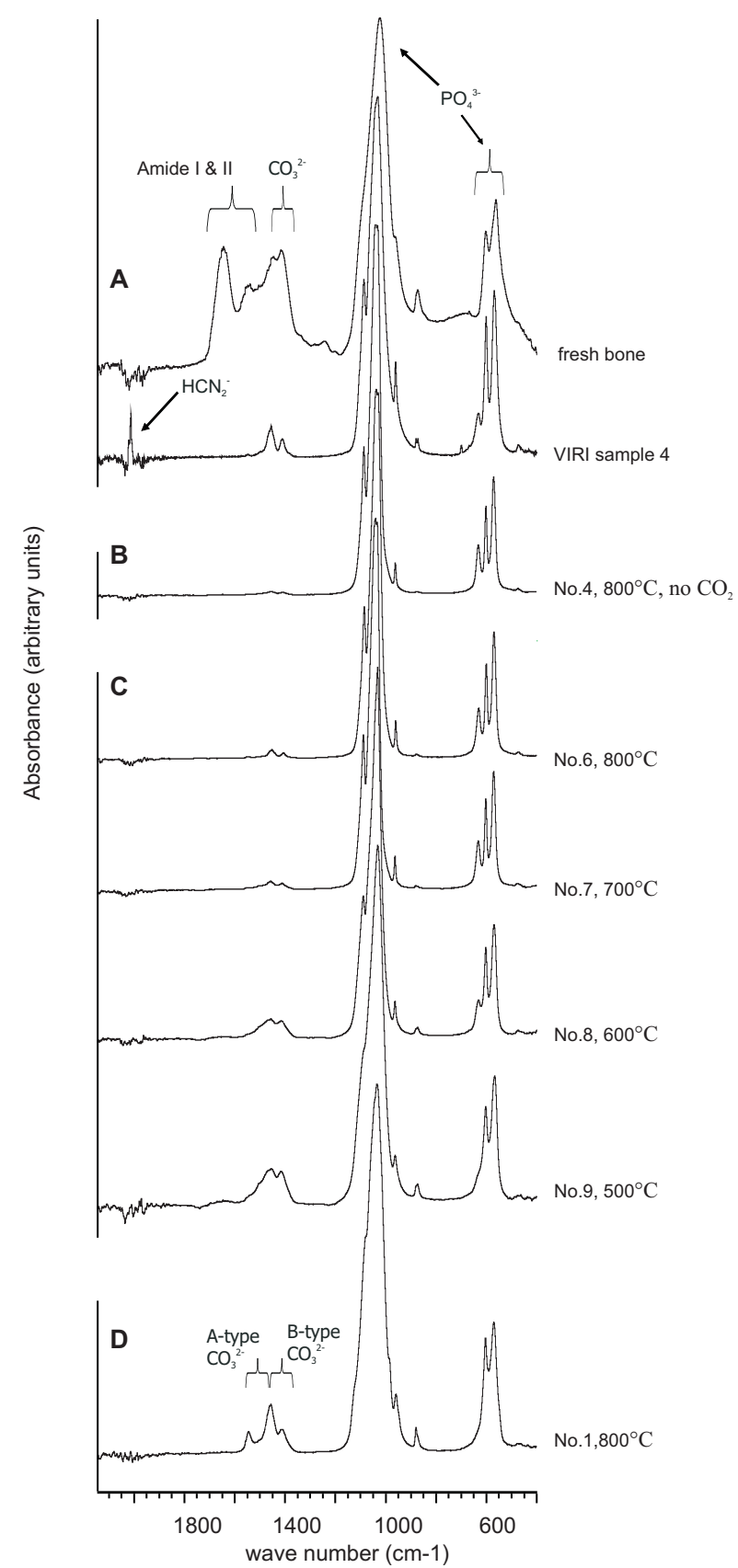

Figure 3 Selection of FTIR spectra of A) fresh bovine bone and an archaeological cremated bone from the VIRI intercomparison (VIRI sample 4, Naysmith et al. 2007), B) cremated bone material without old $\mathrm{CO}_{2}$ (wet conditions), $\mathrm{C}$ ) cremated and burnt bone with old $\mathrm{CO}_{2}$ from $500{ }^{\circ} \mathrm{C}-800{ }^{\circ} \mathrm{C}$ (wet conditions), and D) cremated bone material with old $\mathrm{CO}_{2}$ at $800{ }^{\circ} \mathrm{C}$ (dry conditions). Typical absorption peaks for organic and inorganic fractions are indicated. 


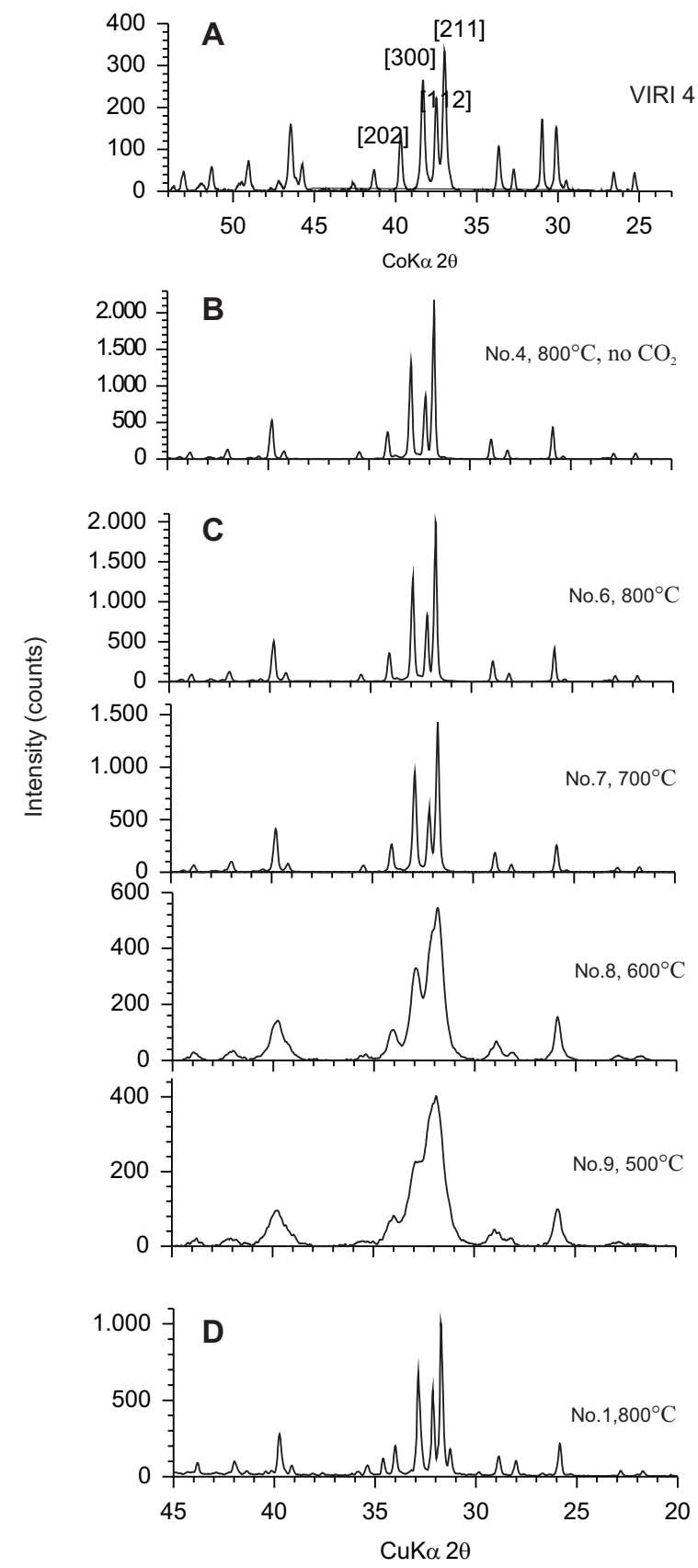

Figure 4 Selection of XRD powder pattern of: A) archaeological cremated bone from the VIRI intercomparison (VIRI sample 4, Naysmith et al. 2007); B) cremated bone material without old $\mathrm{CO}_{2}$ (wet conditions); C) cremated and burnt bone with old $\mathrm{CO}_{2}$ from $500{ }^{\circ} \mathrm{C}-800{ }^{\circ} \mathrm{C}$ (wet conditions); and $\mathrm{D}$ ) cremated bone material with old $\mathrm{CO}_{2}$ at $800{ }^{\circ} \mathrm{C}$ (dry conditions). Typical XRD peaks for hydroxylapatite crystal planes are indicated in the upper panel. 
Another chemical difference is observed between material cremated under wet conditions in comparison to archaeological cremated bone apatite. FTIR of true cremated bone material (i.e. the VIRI 4 sample in Figure 3) shows a prominent vibration intensity around $2012 \mathrm{~cm}^{-1}$, which is absent in the cremated bone material of the experiments discussed here. This specific infrared (IR) frequency is related to the formation of cyanamide-apatite $\mathrm{Ca}_{9}\left(\mathrm{PO}_{4}\right)_{5}\left(\mathrm{HPO}_{4}\right)\left(\mathrm{HCN}_{2}\right)$, formed during heating of the apatite under an ammonia atmosphere (Dowker and Elliott 1979; Habelitz et al. 2001). Interestingly, this species is observed in cremated bones when cremation can be assumed to have occurred along with all body tissues (skin, muscles, fat, etc.), i.e. body cremation. This specific IR frequency is not observed where the archaeological finds indicate cremation of defleshed bone, e.g. in bone waste from a meal, which became cremated after thrown in a camp fire. In addition, cyanamide-apatite is also indicated by FTIR from cremated bone material studied by Van Strydonck et al. (2010), who used modern bone material together with the attached body tissue for cremation experiments. Regarding these observations, we suggest that the formation of cyanamide-apatite is linked to the cremation of bones with attached body tissue and thus may serve as an indicator for real cremation. Aside from the remaining carbonate, the incorporation of a cyanamide group $\left(\mathrm{HCN}_{2}^{-}\right)$ delivers additional carbon to the resulting cremated apatite.

\section{Isotopic Changes}

Apatite carbon isotopes $\left({ }^{14} \mathrm{C},{ }^{13} \mathrm{C}\right)$ were analyzed on the experimentally burnt and cremated bone by AMS. For some samples, a parallel measurement of the apatite $\delta^{13} \mathrm{C}$ was made with conventional MS (Table 3). Overall, the agreement between AMS and MS $\delta^{13} \mathrm{C}$ measurements is high $(n=5, R=$ $\left.1 ; \delta^{13} \mathrm{C}_{\mathrm{AMS}}=0.99 \delta^{13} \mathrm{C}_{\mathrm{MS}}+0.17\right)$.

The isotopic signals measured in the burnt and cremated bone apatite samples document large and significant changes in the apatite carbonate (Table 3). Low ${ }^{14} \mathrm{C}$ and ${ }^{13} \mathrm{C}$ concentrations are seen in samples cremated at $800{ }^{\circ} \mathrm{C}$ with old $\mathrm{CO}_{2}$. The wet cremation with a $\mathrm{CO}_{2}$ concentration of 14.3 vol $\%$ gave ${ }^{14} \mathrm{C}$ values between $\sim 40$ to $50 \mathrm{pMC}$ (Table 3, experiment 6). Using Equation 2 and uncorrected ${ }^{14} \mathrm{C}$ values, an apparent carbon exchange with the old $\mathrm{CO}_{2}$ of about $54-64 \%$ is indicated. These results agree with recent findings of Van Strydonck et. al. (2010), who ran cremation experiments under more natural conditions using modern bone with remaining tissue and old coal at similar temperatures. Lower old $\mathrm{CO}_{2}$ concentrations during cremation result in a slightly lower carbon exchange of $50 \%$ and $36 \%$ (Table 3 , experiment $5, \mathrm{CO}_{2} \sim 10 \mathrm{vol} \%$; experiment $3, \mathrm{CO}_{2} \sim 1.7 \mathrm{vol} \%$ ). At temperatures $\leq 600{ }^{\circ} \mathrm{C}$, estimated carbon exchange is lower, $\sim 22 \%$ at $600{ }^{\circ} \mathrm{C}$ and $11 \%$ at $500{ }^{\circ} \mathrm{C}$, which is in accordance with the lower crystallographic changes.

The largest carbon exchange is indicated by ${ }^{14} \mathrm{C}$ measurements on apatite cremated at $800{ }^{\circ} \mathrm{C}$ under dry conditions (Table 3, experiments 1 and 2). For experiment $1,{ }^{14} \mathrm{C}$ values of 21.92 and $25.84 \mathrm{pMC}$ indicate an exchange of $80.2 \%$ and $76.6 \%$, respectively. Experiment 2 ran longer, $7.5 \mathrm{hr}$ instead of $4.2 \mathrm{hr}$ and the measured ${ }^{14} \mathrm{C}$ value of $15.47 \mathrm{pMC}$ indicates an even larger carbon exchange of $\sim 86 \%$. The larger carbon exchange can be explained by carbonate substituted for $\mathrm{OH}^{-}$(A-type) and for $\mathrm{PO}_{4}{ }^{3-}$ (B-type), while wet-cremated apatite shows carbonate only at the $\mathrm{PO}_{4}{ }^{3-}$ position (B-type). This fact is also seen in higher carbon contents of dry compared to wet cremated apatite (carbon weight fractions $\sim 0.7$ to 0.8 versus $\sim 0.1$ to $0.2 \mathrm{wt} \% \mathrm{C}$ ). It is therefore quite evident that changes in cremation conditions, such as availability of water vapor, may strongly affect carbon exchange.

Measured ${ }^{14} \mathrm{C}$ values from burnt bone apatite thus imply a significant carbon exchange with $\mathrm{CO}_{2}$ from the burning atmosphere, which, in the case of a natural cremation, would come from the burning fuel (e.g. wood). Since the wood used for cremation may partly be old, cremated bones could also suffer from an old-wood effect. Depending on the circumstances of the cremation (temperature, 
duration, composition of the burning atmosphere, and composition/age of the fuel [nearly fresh or old wood]), an age effect of 50-100 yr may be possible, which could get even larger when a significant amount of "old" fuel is used (e.g. peat, coal).

If we assume only apatite carbonate and old $\mathrm{CO}_{2}$ as carbon sources and ignore isotopic fractionation, we can also use the large difference in $\delta^{13} \mathrm{C}$ values between the original bone apatite and the old $\mathrm{CO}_{2}$ (about $-4 \%$ and $-32 \%$, respectively) to estimate carbon exchange. As shown in Table 3, the carbon exchange calculated from $\delta^{13} \mathrm{C}$ is significantly larger than the exchange based on ${ }^{14} \mathrm{C}$. This discrepancy indicates that other factors, such as isotopic fractionation and carbon derived from collagen or post-burning contamination, need to be considered.

Two wet-cremation experiments ( 4 and 11; Table 3 ), run without old $\mathrm{CO}_{2}$ loading in order to address this issue, show depleted values for both ${ }^{13} \mathrm{C}$ and ${ }^{14} \mathrm{C}$. Collagen and apatite carbonate have similar ${ }^{14} \mathrm{C}$ and different ${ }^{13} \mathrm{C}$ concentrations, so admixture of collagen carbon will cause only a ${ }^{13} \mathrm{C}$ depletion, and cannot explain the observations. Fractionation will affect both isotopes and, if we assume the usual mass difference dependence, we can use the measured $\delta^{13} \mathrm{C}$ values to calculate the ${ }^{14} \mathrm{C}$ values to expect. For experiments 4 and $11, \delta^{13} \mathrm{C}$ values are depleted by $3.3 \%$ and $9.3 \%$, respectively, relative to the original bone apatite, which translates to a predicted decrease of 0.73 and $2.04 \mathrm{pMC}$ in ${ }^{14} \mathrm{C}$, significantly less than the observed decrease of 1.76 and $4.32 \mathrm{pMC}$. Thus, fractionation alone cannot explain the observations.

Figure 5 gives the measured ${ }^{14} \mathrm{C}$ (uncorrected for ${ }^{13} \mathrm{C}$ fractionation) and $\delta^{13} \mathrm{C}$ values of the burnt and cremated apatite samples. All samples show a deviation from a mixing line between original apatite carbonate and old $\mathrm{CO}_{2}$ isotopic composition with consistently lower $\delta^{13} \mathrm{C}$ values. This difference is

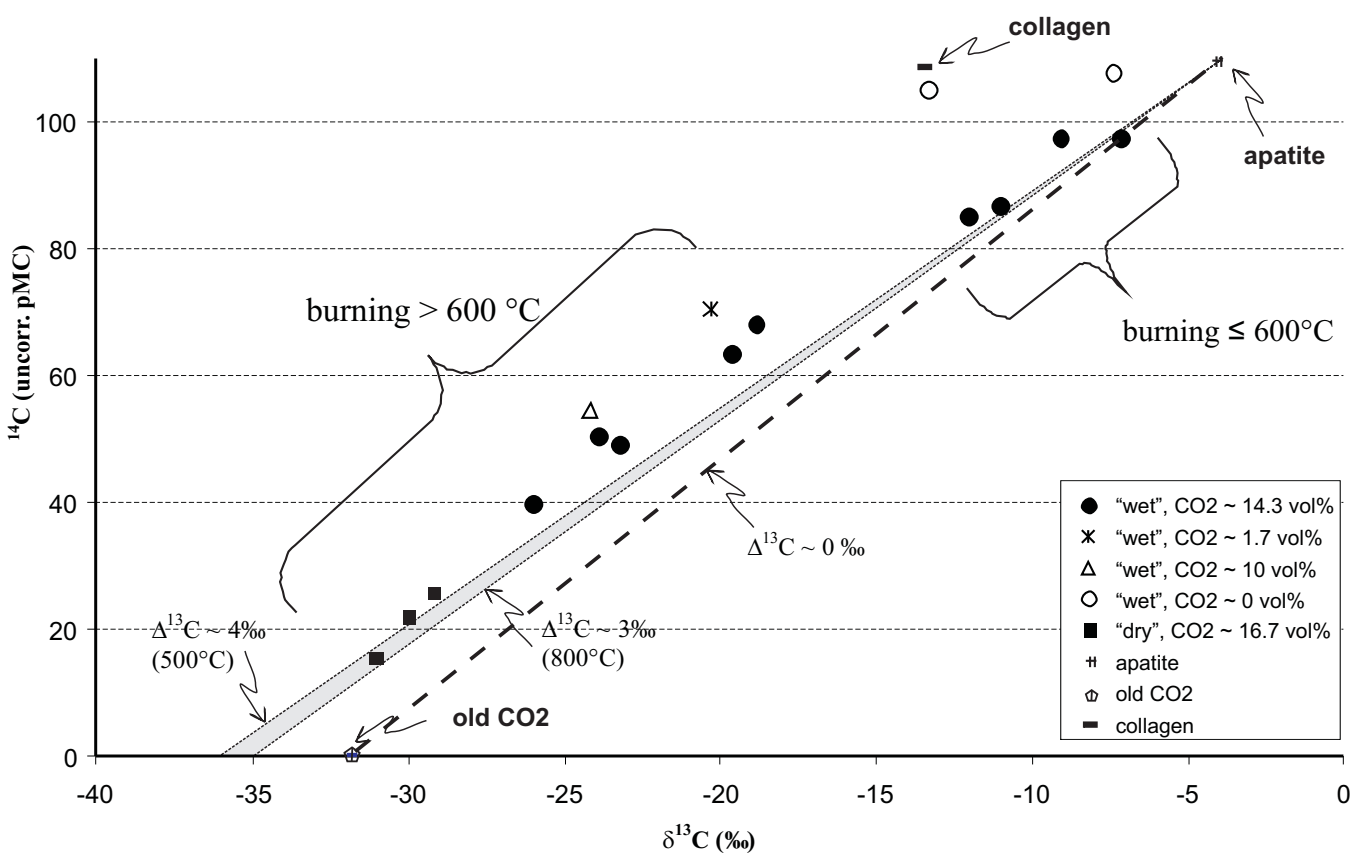

Figure $5{ }^{14} \mathrm{C}$ (uncorrected for ${ }^{13} \mathrm{C}$ ) versus $\delta^{13} \mathrm{C}$. The black dotted line represents the mixing line between old $\mathrm{CO}_{2}$ and bone apatite carbonate without fractionation. The gray field is defined by mixing lines with a ${ }^{13} \mathrm{C}$ fractionation of $-3 \%$ at $800{ }^{\circ} \mathrm{C}$ and $-4 \%$ at $500{ }^{\circ} \mathrm{C}$, respectively, for an isotope system of $\mathrm{CO}_{2}$ to $\mathrm{CaCO}_{3}$ in equilibrium (Bottinga 1969; Scheele and Hoefs 1992). The ${ }^{14} \mathrm{C} /{ }^{13} \mathrm{C}$ end-members for collagen, apatite, and old $\mathrm{CO}_{2}$ are indicated. 
apparently lower at temperatures $<600^{\circ} \mathrm{C}$ at which changes in crystal properties, carbonate loss, and estimated carbon exchange are also low, and high at temperatures $>600{ }^{\circ} \mathrm{C}$ with a large exchange between $\mathrm{CO}_{2}$ and apatite. This is as expected from thermal decomposition (Zazzo et al. 2009) and from studies of the calcite- $\mathrm{CO}_{2}$ system in thermodynamic equilibrium at high temperatures (Bottinga 1969; Scheele and Hoefs 1992) that report a calcite ${ }^{13} \mathrm{C}$ depletion relative to $\mathrm{CO}_{2}$ of $\sim 4 \%$ at $500{ }^{\circ} \mathrm{C}$ and $3 \%$ at $800{ }^{\circ} \mathrm{C}$. Assuming this relation to hold for our apatite system, the apatite carbonate in equilibrium with the old $\mathrm{CO}_{2}$ should have $\delta^{13} \mathrm{C}$ values of $-35 \%$ to $-36 \%$ o $\left(800\right.$ to $\left.500{ }^{\circ} \mathrm{C}\right)$, which gives a mixing field closer to, but still less negative, than the observed values. Use of the depleted carbonate values as end-members gives a relative reduction of the ${ }^{13} \mathrm{C}$-calculated exchange values in Table 3 of about $10 \%$, bringing them closer to, but still not in agreement with, the ${ }^{14} \mathrm{C}$ based values. For the dry cremation with $\mathrm{CO}_{2}$ at $800{ }^{\circ} \mathrm{C}$ (experiments 1 and 2), the change is particularly important as the reduction in the ${ }^{13} \mathrm{C}$-based exchange is especially large here and brings it relatively close to the ${ }^{14} \mathrm{C}$-based values.

Although contamination with atmospheric $\mathrm{CO}_{2}$ during the cremation experiment can be excluded in the sealed combustion system, a post-burning contamination of an activated apatite formed by carbonate loss during combustion is possible after removal of the sample from the combustion system, especially during sample grinding for $\mathrm{AMS} \mathrm{CO}_{2}$ extraction. Isotopically light laboratory air depleted in ${ }^{14} \mathrm{C}$ (such as from the use of dry ice in the lab rooms) may have contributed to the residual ${ }^{14} \mathrm{C}$ depletion observed for samples 4 and 10 after fractionation correction. Unfortunately, we do not yet have isotope measurements $\left({ }^{14} \mathrm{C},{ }^{13} \mathrm{C}\right)$ of laboratory atmospheric $\mathrm{CO}_{2}$ to quantify this possibility. Clearly, more tests are needed to rule out the possibility of post-burning/cremation contamination or to understand fully the dynamics of the cremation process.

\section{CONCLUSIONS}

Infrared spectroscopy (FTIR) and X-ray diffractometry (XRD) confirm the complete loss of organics, loss of carbonates, and significant crystallographic changes in cremated bone apatite. They also reveal a difference in carbonate substitution between apatites cremated at $800{ }^{\circ} \mathrm{C}$ wet: water available, $\mathrm{CO}_{3}{ }^{2-}$ only substituted for $\mathrm{PO}_{4}{ }^{3-}$ (B-type, being the main type of carbonate substitution in bone apatite); and dry: no water, B-type with additional substitution of $\mathrm{CO}_{3}{ }^{2-}$ for $\mathrm{OH}^{-}$(A-type). Dry cremation showed a much lower carbonate loss.

${ }^{14} \mathrm{C}$ concentrations and $\delta^{13} \mathrm{C}$ values of burnt and cremated apatite indicate significant carbon exchange with $\mathrm{CO}_{2}$ in the combustion atmosphere - up to $64 \%$ (wet cremation) and $86 \%$ (dry cremation), both based on ${ }^{14} \mathrm{C}$ values - which varies with $\mathrm{CO}_{2}$ concentration and duration. Archaeological cremated bone apatite may thus contain a significant amount of carbon originating from the burning fuel, and their ${ }^{14} \mathrm{C}$ dates may thus suffer from an old-wood effect.

$\delta^{13} \mathrm{C}$ values generally yield a much larger calculated carbon exchange than the ${ }^{14} \mathrm{C}$ measurements if any isotope fractionation between $\mathrm{CO}_{2}$ and apatite carbonate is left out of consideration. The discrepancies between the results obtained from paired isotope values show that the isotopic changes of apatite carbonate during burning and cremation are not governed by carbon exchange between apatite carbonate and the combustion gases alone. Temperature-dependent isotope fractionation between combustion $\mathrm{CO}_{2}$ and apatite carbonate, admixture of organic (collagen) carbon, and postcremation contamination with atmospheric $\mathrm{CO}_{2}$ may also have influenced the results. 


\section{ACKNOWLEDGMENTS}

Thanks are due to the Leibniz team for sample preparation and AMS analysis. The discussions and collaboration with Mark Van Strydonck and Mathieu Boudin as well as the comments and suggestions by the reviewers are gratefully acknowledged.

\section{REFERENCES}

Berger R, Horney AG, Libby WF. 1964. Radiocarbon dating of bone and shell from their organic components. Science 144(3621):999-1001.

Bocherens H. 2002. Preservation of isotopic signals $\left({ }^{13} \mathrm{C}\right.$, $\left.{ }^{15} \mathrm{~N}\right)$ in Pleistocene mammals. In: Katzenberg A, editor. Biogeochemical Approaches to Paleodietary Analysis. New York: Kluwer Academic. p 65-87.

Bottinga Y. 1969. Calculated fractionation factors for carbon and hydrogen isotope exchange in the system calcite-carbon dioxide-graphite-methane-hydrogenwater vapor. Geochimica et Cosmochimica Acta 33(1):49-64.

Cazalbou S, Combes C, Eichert D, Rey C. 2004. Adaptive physico-chemistry of bio-related calcium phosphates. Journal of Materials Chemistry 14:2148-53.

De Mulder G, Van Strydonck M. 2004. Radiocarbon dates of two urnfields at Velzeke (Zottegem, East Flanders Belgium). In: Higham T, Bronk Ramsey C, Owen C, editors. Radiocarbon and Archaeology. Proceedings of the 4th Symposium ${ }^{14} \mathrm{C}$ an Archaeology, Oxford, 9-14 April 2002. Oxford University School of Archaeology Monograph. p 247-62.

De Mulder G, Van Strydonck M, Boudin M, Lerclercq W, Paridaens N, Warmenbol E. 2007. Reevaluation of the late Bronze Age and early Iron Age chronology of the western Belgian urnfields based on ${ }^{14} \mathrm{C}$ dating. Radiocarbon 49(2):499-514.

Dowker SEP, Elliott JC. 1979. Infrared absorption bands from $\mathrm{NCO}^{-}$and $\mathrm{NCN}^{2-}$ in heated carbonate-containing apatites prepared in the presence of $\mathrm{NH}^{4+}$ ions. Calcified Tissue International 29(1):177-8.

Elliott JC. 2002. Calcium phosphate biominerals. In: Kohn MJ, Rakovan J, Hughes JM, editors. Phosphates: Geochemical, Geobiological, and Material Importance. Reviews in Mineralogy \& Geochemistry 48:427-54.

Enzo S, Bazzoni M, Mazzarello V, Piga G, Bandiera P, Melis P. 2007. A study by thermal treatment and X-ray powder diffraction on burnt fragmented bones from tombs II, IV and IX belonging to the hypogeic necropolis of "Sa Figu" near Ittiri, Sassari (Sardinia, Italy). Journal of_Archaeological Science 34(10):1731-7.

Habelitz S, Pascual L, Duran A. 2001. Transformation of tricalcium phosphate into apatite by ammonia treatment. Journal of Materials Science 36(17):4131-5.

Lanting AL, Brindley JN. 2000. An exciting new development: calcined bones can be ${ }^{14} \mathrm{C}$-dated. The European Archaeologist 13:7-8

Lanting JN, Aerts-Bijma AT, van der Plicht J. 2001.
Dating of cremated bones. Radiocarbon 43(2A):24954.

Lee-Thorp J, Sponheimer M. 2003. Three case studies used to reassess the reliability of fossil bone and enamel isotope signals for paleodietary studies. Journal of Anthropological Archaeology 22(3):208-26.

LeGeros RZ, Trautz OR, Klein E, LeGeros JP. 1969. Two types of carbonate substitution in the apatite structure. Experientia 25(1):5-7.

Nadeau M-J, Schleicher M, Grootes PM, Erlenkeuser H, Gottdang A, Mous DJW, Sarnthein JM, Willkomm H. 1997. The Leibniz-Labor AMS facility at the Christian-Albrechts-University, Kiel, Germany. Nuclear Instruments and Methods in Physics Research B 123(1-4):22-30.

Nadeau M-J, Grootes PM, Schleicher M, Hasselberg P, Rieck A, Bitterling M. 1998. Sample throughput and data quality at the Leibniz-Labor AMS Facility. Radiocarbon 40(2):239-45.

Nadeau M-J, Grootes PM, Voelker A, Bruhn F, Duhr A, Oriwall A. 2001. Carbonate ${ }^{14} \mathrm{C}$ background: Does it have multiple personalities? Radiocarbon 43(2A): 169-76.

Naysmith P, Scott EM, Cook GT, Heinemeier J, van der Plicht J, Van Strydonck M, Bronk Ramsey C, Grootes PM, Freeman SPHT. 2007. A cremated bone intercomparison study. Radiocarbon 49(2):403-8.

Olsen J, Heinemeier J, Bennike P, Krause C, Hornstrup KM, Thrane H. 2008. Characterisation and blind testing of radiocarbon dating of cremated bone. Journal of Archaeological Science 35(3):791-800.

Person A, Bocherens H, Saliège J-F, Paris F, Zeitoun V, Gérard M. 1995. Early diagenetic evolution of bone phosphate: an X-ray diffractometry analysis. Journal of Archaeological Science 22(2):211-21.

Piga G, Malgosa A, Thompson TJU, Enzo S. 2008. A new calibration of the XRD technique for the study of archaeological burned human remains. Journal of Archaeological Science 35(8):2171-8.

Scheele N, Hoefs J. 1992. Carbon isotope fractionation between calcite, graphite and $\mathrm{CO}_{2}$ : an experimental study. Contributions to Mineralogy and Petrology 112(1):35-45.

Shipman P, Foster G, Schoeninger M. 1984. Burnt bones and teeth: an experimental study of color, morphology, crystal structure and shrinkage. Journal of Archaeological Science 11(4):307-25.

Skinner HCW. 2005. Biominerals. Mineralogical Magazine $69(5): 621-41$. 
Stiner MC, Kuhn SL, Weiner S, Bar-Yosef O. 1995. Differential burning, recrystallization, and fragmentation of archaeological bone. Journal of Archaeological Science 22(2):223-37.

Surovell TA. 2000. Radiocarbon dating of bone apatite by step heating. Geoarchaeology 15(6):591-608.

Tamers MA, Pearson FJ. 1965. Validity of radiocarbon dates on bones. Nature 208(5015):1053-5.

Trueman CNG, Behrensmeyer AK, Tuross N, Weiner S. 2004. Mineralogical and compositional changes in bones exposed on soil surfaces in Amboseli National Park, Kenya: diagenetic mechanisms and the role of sediment pore fluids. Journal of Archaeological Science 31(6):721-39.
Van Strydonck M, Boudin M, Hoefkens M, De Mulder G. 2005. ${ }^{14} \mathrm{C}$-dating of cremated bones, why does it work? Lunula Archaeologia Protohistorica XIII 18: 148.

Van Strydonck M, Boudin M, De Mulder G. 2010. The origin of the carbon in bone apatite of cremated bones. Radiocarbon 52(2-3):578-86.

Weiner S, Bar-Yosef O. 1990. States of preservation of bones from prehistoric sites in the Near East: a survey. Journal of Archaeological Science 17(2):187-96.

Zazzo A, Saliège J-F, Person A, Boucher H. 2009. Radiocarbon dating of calcined bones: Where does the carbon come from? Radiocarbon 51(2):1-12. 